\title{
KONSTRUKSI REALITAS DALAM INFOTAINMENT SILET
}

\author{
Siti Mariyam \\ Program Studi Kajian Komunikasi dan Masyarakat Islam Pascasarjana Universitas Islam \\ Negeri Sunan Kalijaga, Jl. Marsda Adisucipto Yogyakarta, 55281, No Hp. 087850347295 \\ E-mail: stiemaryam12ribie@gmail.com
}

\begin{abstract}
This paper aims to analyze the discourse of motto used by Silet, the most favorite infotainment programs of Panasonic Gobel Awards. The research found that Silet has used language that can transform reality. Using language, Silet has constructed meaning to audiences that information presented has changed from original form. Something that is taboo now can be worthy to discuss it after broadcasted by Silet. Silet gives suggestion and 'false consciousness' to audiences that everything presented by Silet is good and right. The use of words and motto is a tactic to make proper banality of news content presented by Silet.
\end{abstract}

Key Words: Construction of reality, Infotainment, Discourse Analysis

\begin{abstract}
Abstrak
This paper aims to analyze the discourse of motto used by Silet, the most favorite infotainment programs of Panasonic Gobel Awards. The research found that Silet has used language that can transform reality. Using language, Silet has constructed meaning to audiences that information presented has changed from original form. Something that is taboo now can be worthy to discuss it after broadcasted by Silet. Silet gives suggestion and 'false consciousness' to audiences that everything presented by Silet is good and right. The use of words and motto is a tactic to make proper banality of news content presented by Silet.
\end{abstract}

Kata Kunci : Konstruksi Realitas, Jurnalistik Infotainment, Analisis Wacana

\section{Pendahuluan}

Media memiliki kekuatan dan otoritas untuk mengendalikan wacana tertentu di ruang publik. Media sebagai alat pencetak opini publik terhadap kasus-kasus yang sedang berlangsung diberitakan (Eriyanto, 2001:56).Di balik sebuah pemberitaan tentu bukan tanpa dasar dan alasan, media pasti memiliki maksud dan tujuan tersendiri serta mempunyai wacana tertentu yang ingin disampaikan kepada khalayak.

Dalam pandangan kaum konstruksionis, apa yang disampaikan oleh media pada dasarnya adalah hasil dari konstruksi dan semua hasil konstruksi memberi andil bagaimana realitas tersebut hadir di hadapan khalayak
(Eriyanto, 2001:26).Maka, setiap realitas yang ditampilkan oleh media termasuk infotainment Silet tentu dikonsep sesuai dengan maksud dan tujuannya, dengan dikonstruksi sedemikian rupa untuk membentuk wacana tertentu, sehingga membawa konsekuensi tertentu ketika diterima oleh khalayak.

Infotainment Silet yang merupakan infotainment terfavorit bagi pemirsa dalam versi Panasonic Gobel Awards (www. creativeindigo.net, akses 30 Desember 2015).Dengan fakta yang demikian, tentu memiliki penonton yang lebih banyak dan mempunyai potensi yang lebih luas untuk membentuk wacana yang lebih dominan. Dengan demikian, pemberitaan yang dimuatoleh infotainment Silet juga 
akan sangat berpengaruh pada wacana yang berkembang di masyarakat, karena tingkat kepercayaan khalayak pada infotainment Silet lebih tinggi daripada infotainment yang lain.

Fakta di atas, menjadi alasan penting dibalik peneliti menggunakan infotainment Silet sebagai objek penelitian. Dalam penelitian ini peneliti fokus meneliti motto dari infotainment Silet, karena motto merupakan kalimat, frasa atau kata yang digunakan sebagai semboyan dan pedoman atau prinsip (kbbi.co.id, akses 30 Desember 2015) yang akan menggambarkan serta menentukan tujuan dan arah pemberitaan infotainment Silet.

Konsep infotainment awalnya berasal dari John Hopkins University (JHU). Ide dasar konsep infotainment berawal dari asumsi bahwa informasi dibutuhkan oleh masyarakat, tetapi informasi tidak dapat diterima begitu saja, apalagi untuk mengubah sikap negatif manusia menjadi positif, sehingga dibutuhkan pancingan agar mendapat perhatian masyarakat. Pilihannya adalah dengan cara menyusupkan entertainment (hiburan) dalam menyampaikan information (informasi). Dari sini muncullah istilah infotainment, yaitu informasi yang dibungkus dan disisipi dengan hiburan untuk menarik perhatian khalayak(Iswandi Syahputra, 2006:65).

Bila kita merujuk pada latar belakang historis munculnya konsep infotainment, maka seharusnya ia bermakna informasi yang dikemas dalam bentuk hiburan. Informasi sebagai inti acara yang disampaikan kepada publik dengan menggunakan metode atau cara yang menghibur. Oleh sebab itu, sejatinya infotainment merupakan konten atau program media yang tetap didasarkan pada informasi, yang juga mengandung konten hiburan dengan tujuan untuk meningkatkan popularitas penonton (Iswandi Syahputra, 2013:94). Anehnya, makna infotainemnt yang terjadi dalam industri televisi Indonesia adalah informasi tentang hiburan. Sisi hiburannya dijadikan subtansi untuk disampaikan kepada khalayak (Iswandi Syahputra, 2006:67).

Infotainment yang berkembang saat ini, merupakan kultur baru industri media massa yang tengah mengalami proses normalisasi untuk diterima sebagai kerja jurnalistik. Pergulatan dan perdebatan wacana seputar infotainment sebagai produk jurnalistik atau bukan merupakan bagian yang tidak terpisahkan dari terbentuknya kultur baru jurnalisme dalam lingkungan industri media massa. Pihak pertama mengatakan karya jurnalistik hanya pekerjaan melaporkan berita sebagai subyek yang cukup serius, dimana standart jurnalistik umum dijunjung oleh reporter. Sementara pihak kedua meyakini bahwa berita selain penting untuk masyarakat juga dapat menjadi produk yang dapat dibisniskan. Pandangan pihak kedua ini telah memotong apapun dari jurnalisme profesional menjadi apa yang sering disebut sebagai softnews atau infotainment (Iswandi Syahputra, 2013:114).

Para ahli komunikasi dan media menyebutkan bahwa infotainment adalah soft journalism atau soft news, jenis jurnalisme yang menawarkan berita-berita sensasional, lebih personal, dengan selebriti sebagai perhatian liputannya(Iswandi Syahputra, 2006:68). Dengan lahirnya terminologi baru yang menempatkan infotainment sebagai soft news atau soft journalism seharusnya mampu memberikan penekanan lebih pada kerja jurnalistik sebagai hard news atau hard journalism pada penulusuran, pengecekan fakta, dan kepentingan publik, dibandingkan infotainment sebagi rivalnya(Iswandi Syahputra, 2013:114).

Pengkategorian antara infotainment 
sebagai soft news dengan jurnalisme sebagai hard news menjadi penting diketengahkan. Kendati keduanya dapat diterima masuk dalam 'rumah jurnalisme', tetapi harus diletakkan dalam kamar yang berbeda. Pembedaan keduanya dapat disusun berdasarkan pemberitaan sejumlah kategori sebagai berikut (Iswandi Syahputra, 2013:115): a) Hard news secara konseptual meliputi bidang liputan; 1) Seriousnes, seperti bidang politik, ekonomi, kriminal, perang dan bencana yang dianggap sebagai topik serius, begitu juga beberapa aspek dari hukum, bisnis, sains dan teknologi. 2) Timelines berupa kisah yang meliput kejadian terkini-kelanjutan suatu perang, hasil dari pemilihan umum, pecahnya peperangan, pernyataan penting, kriminalitas, atau laporan ekonomi. Dan b) Soft news yang merujuk pada infotainment secara konseptual meliputi bidang liputan; 1) Subjek pemberitaan yang kurang serius atau tidak memiliki muatan kepentingan bagi publik, seperti seni dan hiburan, olah raga, gaya hidup, human interest, dan selebriti. 2) Tidak ada timelines seperti kejadian tertentu yang memicu kisah tersebut, selain dari keingintahuan reporter belaka.

Prospek infotainment kedepan masih besar, karena didukung oleh melonggarnya regulasi dan tingginya minat masyarakat terhadap informasi dan hiburan yang ditayangkan oleh infotainment. Dengan demikian, posisi jurnalistik infotainment juga akan sangat bergantung kemana arah pendulum infotainment bergerak. Bila pendulum digerakkan semata-mata hanya untuk kepentingan sensaional, maka jurnalistik infotainment bukan saja tidak masuk dalam jenis soft journalism, tetapi justru menjadi "not journalism"(Iswandi Syahputra, 2013:120).

\section{Metode Penelitian}

Jenis penelitian ini adalah penelitian kualitatif dengan menggunakan analisis wacana yang merupakan bagian dari metode interpretatif yang mengandalkan interpretasi dan penafsiran peneliti (Alex Sobur, 2002:70). Metode digunakan sebagai upaya untuk menafsirkan maksud tersembunyi yang terkandung dalammotto infotainment Silet.

Objek dalam penelitian ini adalah program acara infotainment Silet di stasiun televisi RCTI. Sementara fokus kajian dalam penelitian ini adalah teks dari motto infotainment Silet.

Teknik pengumpulan data dalam penelitian ini adalah dokumentasi. Data utama diperoleh dari sebuah rekaman atau video dari motto infotainment Silet, karena motto merupakan kalimat, frasa atau kata yang digunakan sebagai semboyan dan pedoman atau prinsip yang menggambarkan sifat atau kegunaan benda itu (kbbi.co.id, akses 30 Desember 2015).Pengambilan sampel motto infotainment Silet yang akan diteliti , karena motto merupakan kalimat, frasa atau kata yang digunakan sebagai semboyan dan pedoman atau prinsip (kbbi.co.id, akses 30 Desember 2015) yang menggambarkan serta menentukan tujuan dan arah pemberitaan infotainment Silet, sehingga penting untuk diketahui makna (eksplisit maupun implisit) yang terkandung dalammotto infotainment Silet.

Data lain yang digunakan untuk menunjang penelitian yaitu diperoleh dari buku, jurnal, artikel dan internet (apabila data yang dibutuhkan tidak diperoleh dari sumber lain).

Setelah terkumpul data-data yang berupa teks dari motto infotainment Silet, peneliti kemudian menganalisis data tersebut dengan menggunakan analisis wacana model Roger Fowler, Robert Hodge, Gunther Kress dan Tony Trew. 
Tabel 1. Kerangka Analisis Roger Fowler Wacara

\begin{tabular}{ll}
\hline \multicolumn{1}{c}{ Tingkat } & \multicolumn{1}{c}{ Hal yang dilihat } \\
\hline Kata: & -Pilihan kosakata yang dipakai untuk \\
& menggambarkan peristiwa. \\
& -Pilihan kata yang dipakai untuk menggambarkan \\
& aktor (agen) yang terlihat dalam peristiwa. \\
& -Bagaimana peristiwa digambarkan lewat rangkaian \\
Kalimat: & kata. \\
\hline
\end{tabular}

(Sumber : Eriyanto, 2001:165)

Roger Fowler dkk lebih menekankan padapenelitian elemen kata dan tata bahasa (Eriyanto, 2001:133).

Dalam membangun model analisisnya, Roger Fowler dkk membuat kerangka analisis wacana pada Tabel 1.

Dua elemen Roger Fowler dkk di atas merupakan satu rangkaian yang akan menunjukkan konstruksi realitasdalam infotainment Silet. Inti analisis Roger Fowler dkk adalah ingin melihat bagaimana realitas dibahasakan oleh media dan bagaimana bahasa yang dipakai itu membawa konsekuensi tertentu ketika diterima oleh khalayak.

\section{Hasil Penelitian dan Pembahasan}

Kata-kata tidaklah dipandang sebagai persoalan teknis semata, tetapi sebagai praktik ideologi tertentu, karena bahasa yang berbeda akan menghasilkan realitas yang berbeda pula ketika diterima oleh khalayak(Eriyanto, 2001:134). Dalam kajian semantik ada prinsip umum yang bisa kita pahami, ialah apabila bentuk (maksudnya bentuk kata) berbeda, maka makna akan berbeda, meskipun perbedaannya sedikit (Abdul Chaer, 2009:34).

Untuk mengetahui praktik ideologi yang ada dalam media, salah satunya dapat kita lihat melalui level kata yang digunakan oleh media, sehingga bisa diketahui makna apa yang ingin dikomunikasikan oleh infotainment Silet kepada khalayak.

Ditinjau dari kata-kata yang digunakan dalam motto infotainment Silet, terdapat sejumlah kata-kata yang mempunyai gambaran makna tertentu, sehingga sangat penting untuk dikaji secara teoretis, karena penggunaan kosakata tersebut tidak hanya sekedar masalah teknis saja namun lebih dari itu merupakan bentuk praktik ideologi untuk mengkonstruksi wacana yang ingin dibangun oleh infotainment Silet, sehingga menyediakan ruang bagi khalayak agar bagaimana realitas harus dipahami (sesuai dengan wacana yang dikonstruksi oleh infotainment Silet).

Kosakata sebagai Pembatasan Pandangan

Kosakata juga dikategorikan sebagai pembatasan pandangan(Eriyanto, 2001:137). Artinya tingkat referensial yang dikandung oleh kata selalu berkaitan dengan kondisi dan keadaan subjektifitas media yang mengatur produksi kosakata tertentu, sehingga kata di sini berfungsi sebagai batasan atau semacam kendali yang diterapkan terhadap khalayak(Howard Davis dan Paul Walton, 2010:293).

Pilihan kosakata yang digunakan dalam motto infotainment Silet menunjukkan bagaimana infotainment Silet melihat dan memaknai realitas. Selain itu kosakata tersebut juga berfungsi untuk mengendalikan pikiran khalayak sesuai dengan apa (makna) yang ingin dikonstruk oleh infotainment Silet. Hal tersebut dibahasakan dengan kosakata berikut,

"Selama satu jam kedepan, "Silet" hadir untuk mengupas tuntas kisah dan kasus para selebriti tanah air, serta mengangkat hal-hal yang di anggap tabu, menjadi layak dan patut diperbincangkan. Yang akan dikupas secara tajam, setajam Silet" (www.creativeindigo.net, akses 30 Desember 2015).

Kalimat di atas merupakan motto (semboyan, pedoman atau prinsip) 
dari infotainment Silet yang diucapkan saat membuka acara. Pilihan kata yang digunakan tersebut tidak bisa dipandang sebagai sesuatu yang bisa kita terima begitu saja. Pemakaian kata bukan semata masalah istilah belaka, karena katakata menimbulkan arti dan pemaknaan tertentu ketika diterima oleh khalayak (Eriyanto, 2001: 149).

Sebagai sebuah diskursus media tidak dapat dipisahkan dari kesalingberkaitan antara bahasa yang digunakan di dalamnya serta bentuk-bentuk kepentingan yang beroperasi di baliik bahasa tersebut. Artinya, perbincangan mengenai media tidak dapat dipisahkan dari ideologi yang membentuknya, yang pada ahirnya mempengaruhi bahasa yang ia gunakan (kosakata dan tata bahasa) dan realitas yang dihasilkannya (Yasraf Amir Piliang, 2005: 214). Hal yang menarik untuk dikaji dalam kalimat di atas adalah bagaimana infotainment Silet memaknai dan menyebutkan halhal yang dianggap tabu menjadi layak dan patut diperbincangkan. Pilihan kata "tabu, layak dan patut" menunjukkan bagaimana infotainment Silet dalam memaknai sebuah realitas.

Dalam Kamus Besar Bahasa Indonesia kata "tabu" memilikiarti sebuah pantangan atau larangan (Depdikbud Indonesia, 2005:881). Artinya, suatu tindakan yang dilarang, dihindari atau suatu pelarangan sosial yang kuat terhadap kata, benda, tindakan, atau perbuatan orang yang dianggap tidak diinginkan oleh suatu kelompok, budaya, dan masyarakat. Sedangkan kata "layak dan patut" memiliki arti sesuatu yang wajar, pantas dan merupakan suatu perbuatan yang baik (Depdikbud Indonesia, 2005: 509 dan 654).

Dari pilihan kata-kata di atas adalah untuk menegaskan bahwa segala sesuatu (kisah dan kasus para selebriti tanah air) yang ditayangkan di infotainment
Silet (yang awalnya dilarang atau tidak diinginkan oleh suatu kelompok, budaya, dan masyarakat) telah mengalami perubahan dari wujud aslinya. Halhal yang pada mulanya diakui dan dipercaya sebagai sesuatu yang tabu, tetapi ketika masuk dalam infotainment Silet telah menjadi layak atau pantas, sehingga memang sudah seharusnya untuk dibicarakan atau dijadikan bahan pembicaraan. Penggunaan katakata tersebut memberikan sugesti dan memberikan 'kesadaran palsu' bahwa segala hal yang ditayangkan infotainment Silet adalah hal yang baik dan benar.

Gosip, infotainment dan selebriti adalah teks terbuka yang harus dimaknai secara kontekstual, manakah yang dilarang dan diperbolehkan (Robby $\mathrm{H}$. Abror, 2013: 11).Tidak semuakisah dan kasus para selebritibisadisorot detail hingga ke wilayah yang sangat pribadi,di ekspostanpaverifikasi secara berulangkali layaknya sebuah sinetron. Jika berita yang disampaikan berkisar tentang berita positif selebriti barangkali tidak terlalu menjadi persoalan, akan tetapi berita yang seringkali menarik untuk dikemas dalam infotainment justru berita negatif selebriti. Seperti, konflik rumah tangga, (perselingkuhan, perebutan hak asuh, kawin-cerai), pacaran dan putus pacar,trend: erotisme (Mursito BM, 2011: 9). Dengan demikian, tidak ada lagi batas tegas antara informasi yang "perlu" disampaikan dan yang justru "tabu" atau tidak baik disampaikanpada khalayak.

Program silet dikemas dengan menarik, kemudian berita-berita negatif tentang selebriti dalam infotainment Silet dianggap layak dipertontonkan. Kendati dalam bentuknyayang menarik dan seolah layak dipertontonkan, yang perlu disadari ia tetaplah hal yang diangkat dari sesuatu yang tabu. Berita tersebut terkadang tidak dibiarkan berdiri begitu saja, tetapi infotainment Silet juga mengemas berita 
yang digabung dengan desas-desus yang bersifat gosip. Ironisnya lagi,berita dalam infotainment tidak hanya sampai pada titik menebar rumor, pada tahap tertentu justru merambah pada tahap "mengadu" dengan membenturkan pendapat masing-masing pihak yang sedang berseteru, sehingga tidak heran bila persoalan yang sebenarnya biasa dalam infotainment menjadi sangat keruh(Fransisco Rosarians, www.tempo. co/read/news/2014/03/14/173562168/ KPI-Program-Infotainment-di-TVSemakin-Buruk, akses 30 Desember 2015). Fakta ini membuktikan bahwa informasi yang dibumbui gosip dalam infoinment Silet ini ternyata memiliki dampak yang lebih krusial dibanding diluar layar kaca. Nah, bukankah semestinya secara otomatis dilihat dari dampaknya, "halhal yang dianggap tabu" ketika diangkat ke dalam infotainment Silet dalam bentuk yang demikian semakin menegaskan bahwa ia lebih tabu?

Dengan fakta yang demikian, tentunya infotainemnt (infotainemnt Silet) yang mengkategorikan dirinya sebagai bagian dari ranah jurnalistik, yaitu soft journalism atau soft news telah menodai kode etik jurnalistik itu sendiri, karena ia telah gagal menjunjung keadaan ideal dari tanggungjawabnya sebagai soft journalism yang sejatinya menyajikan informasi yang disampaikan dengan metode hiburan, dalam infotainment Silet justru sisi hiburannya yang dijadikan subtansi untuk disampaikan kepada khalayak. Sejauh sisi hiburan yang disajikan dapat dipertanggungjawabkan sebenarnya tidak masalah, justru masalah menjadi semakin parah, karena pengertian hiburanpun dalam infotainment Silet sudah mengalami distorsi dan penyimpangan makna pula.

Bahasa yang sering terjadi ialah gejala pencitraan, dan tentu berpengaruh besar terhadap khalayak pada umumnya
(Mulyana, 2005: 65). Jadi, penggunaan kata-katadiatastidaklainhanyalahsebuah siasat untuk melayakkan kebanalan isi berita yang disampaikan infotainment Silet, karena dengan kata tersebut bisa memperdaya atau mengelabui daya kritis khalayak terhadap tayangan yang disampaikan infotainment Silet.

\section{Simpulan}

Setelah melakukan analisis terhadap motto infotainment Siletsesuai dengan metode penelitian dalam skripsi ini, maka penulis dapat menarik kesimpulan bahwa dalam mottonya infotainment Silet telah menggunakan bahasa yang dapat mengalihkan realitas. Melalui bahasanya infotainmentSilet mengkonstruksi makna terhadap khalayakbahwa setiap informasi(kisah dan kasus para selebriti tanah air) yang ditayangkan di infotainment Silet (yang awalnya dilarang atau tidak diinginkan oleh suatu kelompok, budaya, dan masyarakat) telah mengalami perubahan dari wujud aslinya. Hal-hal yang pada mulanya diakui dan dipercaya sebagai sesuatu yang tabu, tetapi ketika masuk dalam infotainment Silet telah menjadi layak atau pantas, sehingga memang sudah seharusnya untuk dibicarakan atau dijadikan bahan pembicaraan.

Dengan demikian, infotainment Silet memberikan sugesti dan 'kesadaran palsu' bagi khalayak bahwa segala hal yang ditayangkan infotainment Silet adalah hal yang baik dan benar. Penggunaan kata-kata dalam mottonya tidak lain hanyalah sebuah siasat untuk melayakkan kebanalan isi berita yang disampaikan infotainment Silet, karena dengan kata tersebut bisa memperdaya atau mengelabui daya kritis khalayak terhadap tayangan yang disampaikan infotainment Silet.

Implikasi penelitian ini yaitu; Pertama, media seharusnya menyajikan 
informasi yang dapat membentuk pemahaman yang tidak ambivalensibagi khalayak dalam memaknai sebuah realitas, maupun menyikapi sebuah kasus yang sedang terjadi.Kedua, langkanya penelitian mengenai infotainment, perlulah mendapat perhatian secara serius dari para peneliti, mengingat prospek infotainment kedepan masih besar, karena didukung oleh melonggarnya regulasi dan tingginya minat masyarakat terhadap informasi dan hiburan yang ditayangkan oleh infotainment.

\section{Daftar Pustaka}

Abdul Chaer, Sintaksis Bahasa Indonesia: Pendekatan Proses, Jakarta: Rineka Cipta, 2009.

Alex Sobur, Analisis Teks Media (Pengantar untuk Analisis Wacana, Analisis Semiotika dan Analisis Framing), Bandung: PT. Remaja Rosdakarya, 2002.

Depdikbud Indonesia, Kamus Besar Bahasa Indonesia, Jakarta: Balai Pustaka, 2005.

Eriyanto, Analisis Wacana Pengantar Analisis Teks Media, Yogyakarta: LKiS, 2001.

Analisis Framing: Konstruksi, Ideologi dan Politik Media, Yogyakarta: LKiS, 2007.

Davis, Howard dan Paul Walton, Bahasa, Citra, Media, terj. Ikramullah Mahyuddin, Yogyakarta: Jalasutra, 2010.
Iswandi Syahputra, Jurnalistik Infotainment, Yogyakarta. Pilar Media, 2006.

Rezim Media: Pergulatan Demokrasi, Jurnalisme dan Infotainment dalam Industri Televisi, Jakarta: Gramedia Pustaka Utama, 2013.

Mulyana, Kajian Wacana: Teori, Metode dan Aplikasi Prinsip-prinsip Analisis Wacana, Yogyakarta: Tiara Wacana, 2005.

Yasraf Amir Piliang,Transpolitika: Dinamika Politik di dalam Era Virtualitas, Yogyakarta: Jalasutra, 2005.

Jurnal:

Robby H. Abror, "Komodifikasi Gosip dan Selebriti dalam Infotainment:Harapan dan Tantangan bagi Jurnalisme Islam (Perspektif Filsafat Budaya dan Media)". Jurnal Komunikasi dan Penyiaran Islam. Vol I. No I. Januari-April 2013.

Mursito BM, "Realitas Infotainment di Televisi". Komunikasi Massa, Vol IV: II, Juli 2011.

\section{Internet:}

Fransisco Rosarians, "KPI: Program Infotainment di TV Semakin Buruk", http:/ / www.tempo.co/read/ news/2014/03/14/173562168/ K P I - P r o g r a m - In f o t a i n ment-di-TV-Semakin-Buruk

kbbi.co.id

www.creativeindigo.net 